Alexandra Nicolaidis,

Peter M. Nilsson, David Dunér

\title{
Alexandra Kollontai and three Swedish female physicians - friendly relationships around the Soviet ambassador in Stockholm 1930-1945
}

\begin{abstract}
Alexandra Kollontai was the Soviet ambassador to Sweden in the years 1930 to 1945. In Sweden she gained many friends in the peace- and women's movement and among these were several female physicians. This article describes and investigates the friendships between Swedish female physicians and Alexandra Kollontai. The three physicians focused on are Ada Nilsson (1872-1964), Andrea Andreen (1888-1972) and Nanna Svartz (1890-1986). It is found that Kollontai and the physicians became proper friends, although initial contacts between them had political or medical causes.

Keywords: female physicians, history of medicine, Kollontai, Soviet Union, Sweden.

\section{Introduction}

This article is a contribution to the investigation into how Swedish physicians navigated the ideological force-fields before, during and after the Second World War. German contacts with Swedish physicians have been fairly well researched, ${ }^{1}$ but the same cannot be said when it comes

1 Nils Hansson, "Entusiasm, skepsis, distans: studier i svensk-tyska förbindelser inom medicinen 1933-1945" (Phd diss., Lund University Faculty of Medicine Doctoral Dissertation Series 2013:38, 2013).
\end{abstract}


to contacts between Swedish physicians and the Soviet Union. The lack of research concerning Soviet-Swedish relations during the 1930s and the Cold War can partly be due to the lack of material as the Soviet archives are confidential and not available to the general public.

A major character, representing the Soviet Union in Sweden between years 1930 and 1945, was Alexandra Kollontai. Apart from being a figurehead for Soviet ideas, and the official spokesperson for the Soviet Union, she was the first female ambassador in the world. She cultivated several contacts in Sweden and had many close friends among Swedish women. Among these friends were several female physicians and the main focus of this article is to investigate the relationships between Kollontai and three of these - Ada Nilsson, Andrea Andreen and Nanna Svartz.

Previous research has investigated contemporary female groups and organisations, e.g. the Fogelstad Group and Svenska Kvinnors Vänsterförbund (the Swedish Women's Left-Wing Association, SKV). ${ }^{2,3,4}$ However, there exists no research specifically focused on the female physicians and their role within these groups and organisations. Moreover, the female physicians linked to Alexandra Kollontai have not been investigated. In a previous paper the physician Andrea Andreen has been studied, and links to Alexandra Kollontai, one of her close friends, have been mentioned. ${ }^{5}$

\section{Aims}

The main aim of this article is to investigate and analyse the friendly relationships between Alexandra Kollontai and three female physicians in her vicinity from year 1930 when Kollontai started her mission as Soviet minister in Sweden. Currently, we know very little of Kollontai's relationships with famous Swedish physicians but the fact is that she socialised with several of them. We do not know what her intentions in cultivating

2 Lena Eriksson, Drömmen om kamratsamhället: Kvinnliga medborgarskolan på Fogelstad 1925-35 (Stockholm: Carlsson, 1991).

3 Kristina Lundgren, Barrikaden valde mig: Ada Nilsson läkare $i$ kvinnokampen (Stockholm: Wahlström \& Widstrand, 2014).

${ }^{4}$ Ianthe Holmberg ed., 100 år av kvinnokamp Svenska Kvinnors Vänsterförbund 1914-2014 (Mölndal: Svenska Kvinnors Vänsterförbund, 2015).

5 Alexandra Nicolaidis \& Peter M Nilsson, "Läkaren Andrea Andreen - en kontroversiell fredskämpe och Sovjetvän”, Svensk Medicinhistorisk Tidskrift 25 (2021). 
these contacts originally were but these relationships placed her in a prime position to influence Swedish-Soviet contacts within the area of medical science. It was of importance for the Soviet Union to nurture and strengthen cultural and scientific relations with other countries to further their influence in the world. It is feasible that Kollontai's position as friend and supporter of famous Swedish physicians could influence the attitude of the wider medical profession towards the Soviet Union. This particular proposition has not been explored previously but may bring about new knowledge concerning Swedish-Soviet contacts.

The article will focus on three physicians with documented ties to Kollontai-Ada Nilsson, Andrea Andreen and Nanna Svartz. These three physicians were all well-known figures in Sweden and all three were renowned in their own right. The article will investigate links between these three women as well as their links to Kollontai. Moreover, it will study the structure of their relationships and how the different women are connected.

It goes without saying that Kollontai and the female physicians all benefited from their contact with each other. Each party in this web of contacts had their own private agenda, apart from friendship, for cultivating the contacts between them. We will try to describe the advantages each party could hope to gain from the relationship between them and to what extent this would outweigh any possible disadvantages from being known as friends, and accomplices, of each other.

As can be expected, much has been written about Soviet-Swedish diplomatic relations from different angles. A fairly recent publication in this topic that can be mentioned is Peaceful coexistence? Soviet Union and Sweden in the Khrushchev era (2010) by Helene Carlbäck et al. ${ }^{6}$ A dissertation was also published in 2015 that attempted to study how the Soviet Union tried to win the sympathies of the Swedish population between the years 1945 and 1958 through Sweden-Soviet Union societies. ${ }^{7}$ This dissertation provides a good insight in how important it was for the Soviet Union to maintain good cultural and scientific relations with Sweden during the Cold War.

${ }^{6}$ Helene Carlbäck, Alexey Komarov and Karl Molin, Peaceful coexistence? Soviet Union and Sweden in the Khrushchev era (Huddinge: Södertörns högskola, 2010).

7 Olov Wenell, "Sovjetunionen och svenska vänsällskap 1945-1958: sällskapen Sverige-Sovjetunionen som medel i sovjetisk strategi” (PhD diss. Umeå University Department of Historical, Philosophical and Religious studies, 2015). 
The previous research published about Soviet-Swedish diplomatic relations and contemporary female groups and organizations sets the scene for this article. Through studying the above and below mentioned sources a better understanding of the political environment during Kollontai's time in Sweden has been gained.

There exists a lot of previous research regarding Alexandra Kollontai. For example Arkady Vaksberg published a book about Kollontai in 1997. ${ }^{8}$ This book, which is biographic in its structure, focuses mostly on Kollontai's role as a piece in the larger political game and in the Soviet secret service's activities in Stockholm. Isabel de Palencia (Isabel Oyarzábal Smith), a close friend of Kollontai, and the contemporary minister of the Spanish Republic in Stockholm and Helsinki, has also written an extensive biography about Kollontai. ${ }^{9}$ Obviously it can be suspected that some partialness is represented in this book, due to their friendship, but de Palencia still has a unique view of Kollontai's life due to her being a foreign diplomat herself. Kollontai's Scandinavian period has been more detailed in the dissertation of Kaare Hauge from the University of Minnesota in $1971 .{ }^{10}$ However, it does not investigate her relationships with Swedish physicians but rather focuses on her diplomatic efforts. The same goes for Åsmund Egge's article about the role of Kollontai in Soviet diplomacy in Norway and Sweden during the interwar years. ${ }^{11}$

In summary much has already been published about Kollontai - many biographies and scientific works but when it comes to her time in Sweden they seem to mainly focus on her political and diplomatic endeavours and not on any potential friendly relationships with Swedish female physicians. This article is therefore deemed as of note as it brings about a new perspective regarding Kollontai's role in the diplomatic relations between Sweden and the Soviet Union.

8 Arkady Iosifovich Vaksberg, Aleksandra Kollontaj - en biografi, trans. Hans Björkegren (Stockholm: Norstedts, 1997).

9 Isabel de Palencia, Alexandra Kollontay: Ambassadress from Russia (New York: Longmans, Green \& Co., 1947); Isabel de Palencia, Alexandra Michailovna Kollontay: kvinnan - kämpen - diplomaten, trans. Ingrid Påhlman (Stockholm: Medén, 1946).

10 Hauge Kaare, "Alexandra Mikhailovna Kollontai: The Scandinavian Period: 1922-1945” (PhD diss, University of Minnesota, 1971).

11 Åsmund Egge, "Soviet Diplomacy in Norway and Sweden in the Interwar Years: The Role of Alexandra Kollontai" in The Russian Revolutions of 1917: The Northern Impact and Beyond (Boston MA: Academic Studies Press, 2020), 79-98. 


\section{Materials and methods}

The sources that have proved to be most important are extensive letter collections from the personal archives of Ada Nilsson, Andrea Andreen and Nanna Svartz. In total the number of letters and documents studied in these archives lie around 2000 pages. The archives are kept in the Gothenburg University Library and the National Archives in Stockholm. In addition, the diaries of Alexandra Kollontai and the biographies of Kollontai, Nilsson and Svartz have also proven to contribute important information.

The published diary of Kollontai spans from year 1930 to year 1940 and is a quite special piece of history. No other contemporary foreign diplomat or foreign correspondent in Sweden has written a similar diary that can be compared to Kollontai's. ${ }^{12}$ It is therefore an unusual description of the 1930s in Sweden from the perspective of a foreigner. However, it must be kept in mind that the original version of the diary was written by hand, whereas the version that was released for publication from the archives of social and political history in Moscow was type-written. ${ }^{13}$ Kollontai dictated this version to a secretary between the years 1947 and $1951 .{ }^{14}$ This version is a corrected and processed version of the original diary. Therefore Kollontai has, with the benefit of hindsight, removed, or changed, parts of the diary. Her reasons for this are unknown but there are obvious speculations. The most apparent one is that Kollontai wanted to remove anything that could question her position as a loyal follower to Stalin. Both Pavel Dybenko, Kollontai's second husband, and her previous partner Alexander Shliapnikov were lost during the purges in the late 1930s and Kollontai must have been aware that even small deviations from the party agenda could put her, and her family, in danger. ${ }^{15}$

However, Kollontai actually lost her diary for several years. When she suffered a stroke in 1942 her personal secretary Emy Lorentzon, who previously had been instructed in what to do if Kollontai was incapacitated, tried to transport the diaries to Kollontai's close friend Ada Nilsson. ${ }^{16}$

12 Aleksandra Kollontai, Zapiski za 23 goda diplomatičeskoj raboty; Krister Wahlbäck, "Preface" in Aleksandra Kollontai, Aleksandra Kollontajs dagböcker 1930-1940, trans. Lars Olsson (Stockholm: Bonniers, 2008).

13 Ibid., 15.

14 Ibid., 16.

15 Krister Wahlbäck, "Preface" in Aleksandra Kollontajs dagböcker 1930-1940, 27.

16 Ibid., 17. 
An agent from the KGB caught up with her and confiscated the diaries. The diaries were sent to Moscow and Kollontai did not get them back until autumn 1946 when she directly asked Stalin about them. Stalin allowed Kollontai to have her diaries back so perhaps he considered them harmless, or maybe Kollontai was aware that the KGB might investigate the contents of the diary and therefore knowingly avoided any criticism of Stalin. In any case, it is known that parts of the handwritten diary did not end up in the published version, but were found as loose sheets of paper in stacks of documents handed in to the party archives. ${ }^{17}$ These loose sheets of paper mainly contained critical comments that were left out of the published version.

When it comes to Kollontai's biography, it is obvious that it reflects the opinion of the author. She knew that the biography was to be published so she glossed over parts of her life that may put her in bad light. Furthermore, her biography is written with the benefit of hindsight. Thus, the opinions Kollontai voice in the biography may not correspond to those she had at the time of the events described. Finally, the passage of time may affect memory, or change it, so the descriptions of events written down several decades later may not always represent the reality of what happened.

\section{Alexandra Kollontai}

\section{Background}

Alexandra Kollontai was the world's first female government member, the world's first female ambassador and the world's first female diplomat doyen. Kollontai's father was the Russian officer, and later general, Mikhail Alekseevich Domontovich and her mother Alexandra Alexandrovna Masalina left her first husband, with whom she had three children, to marry him. ${ }^{18}$

Her father's family was of noble blood whereas her mother came from a common, albeit rich, partly Finnish background. ${ }^{19}$ When Kollontai was 21 years old she met her second cousin Vladimir Ludvigovich Kollontai,

\footnotetext{
17 Krister Wahlbäck, "Preface" in Aleksandra Kollontajs dagböcker 1930-1940, 19.

18 Alexandra Kollontai, Jag har levt många liv, trans. Irene Mårdh (Moscow: Progress Moskva, 1985), 19.

19 Ibid., 26.
} 
whom she married, despite her family's protests, and they had one child together. In 1896 she accompanied her husband to the textile factories in Krenholm outside of Narva, where Vladimir was working at the time. ${ }^{20}$ Kollontai witnessed the horrific prisonlike working conditions, where many died from tuberculosis in their $30 \mathrm{~s} .{ }^{21}$ This affected her deeply and in 1898 she therefore left Vladimir and left her son to her parents in Saint Petersburg. Kollontai writes in her biography: "I neither want nor can live my life in a blissful domesticity" and that her husband "would have to understand what I wanted with my life and why I had to leave him. If he did not show any understanding for this it would mean that we still could not spend our lives together. My mission could no one get me to abstain from. I would go to those who would free the workers from capitalism, from tsardom." 22

\section{Abroad, exile and revolution}

Alexandra Kollontai initially travelled to Zürich to study economics and later on to several other countries before returning to Russia. ${ }^{23}$ Due to revolutionary actions she had to go into exile in 1908. In 1911 she moved to Berlin where she learnt to know Lenin, although she had already encountered him in 1905 at an illegal meeting. ${ }^{24}$ During her years in exile Kollontai became the main communication link between Lenin and foreign social democrats. ${ }^{25}$ In 1917 Kollontai returned to Russia. She was elected to be part of the executive committee for the workers' and soldiers' soviet in Petrograd. During this time she also met her second husband, the second lieutenant Pavel Dybenko.

20 Alexandra Kollontai, Jag har levt många liv, trans. Irene Mårdh (Moscow: Progress Moskva, 1985), 69.

21 Ibid., 70-71.

22 Alexandra Kollontai, Jag har levt många liv, 83. Translation from Swedish by the authors. Original text: "Jag varken ville eller kunde framleva mitt liv i en sorglös familjevardag" and "tvungen att lämna honom. Visade han ingen förståelse för detta, så betydde det att vi ändå inte skulle vara tillsammans livet ut. Min uppgift kunde ingen förmå mig att avstå ifrån. Jag skulle gå till dem som ville befria arbetarna från kapitalismen, från tsarväldet."

23 Note on Kollontai, written by Ada Nilsson in 1952, available in her personal archive at Gothenburg University Library, Gothenburg.

24 Alexandra Kollontai, Jag har levt många liv, 99.

25 Agneta Pleijel, "Afterword” in Alexandra Kollontaj, Arbetsbiens kärlek (Stockholm: Gidlunds, 1976), 225. 
Kollontai played a role in the October revolution 1917. In October 1917 a shadow government was created by the Bolsheviks and Kollontai was elected the peoples' commissar of social matters. She writes in her biography: "If someone asked me what moment in my life that was the largest and most memorable I would without doubt answer: The moment when the Soviet power was proclaimed." 26

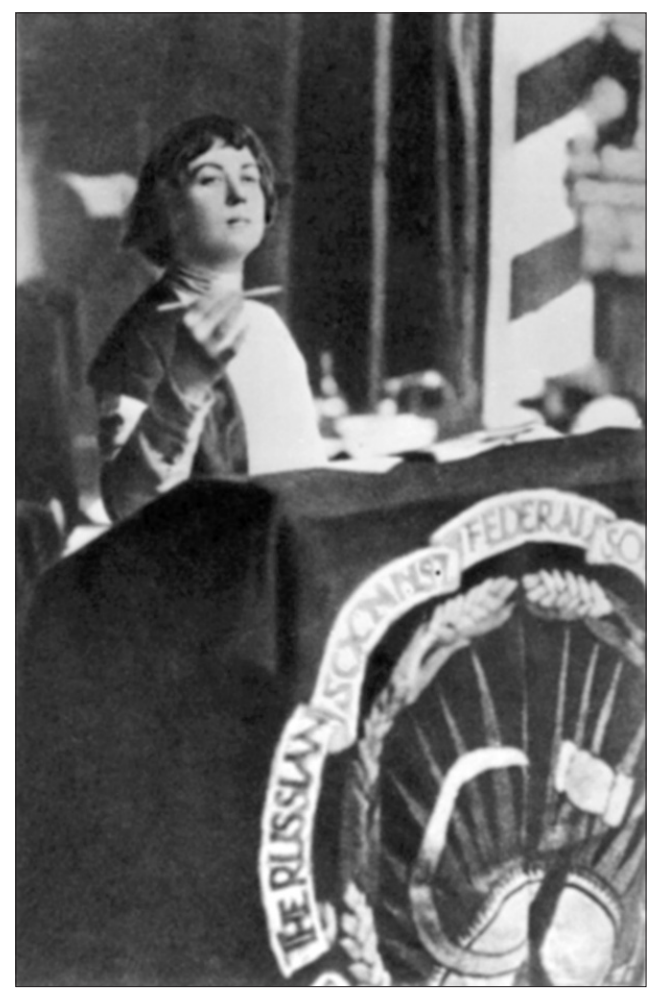

Alexandra Kollontai speaking in Moscow, 1921. Available at TT Nyhetsbyrån News Agency, Stockholm

26 Alexandra Kollontai, Jag har levt många liv, 264. Translated from Swedish by the authors. Original text: "Om någon frågade mig vilken stund i mitt liv som var den största och mest minnesvärda skulle jag utan tvekan svara: Det var den stunden när sovjetmakten proklamerades." 


\section{After the revolution}

After the revolution Kollontai helped to bring about new laws concerning marriage and family. The church's control over marriage was dissolved and laws were based on absolute equality between men and women, and between children born within or outside of wedlock. ${ }^{27}$ Abortion was legalised as a necessary evil and divorce became an easier process. Kollontai was of the mind that the concept of the core family would be dissolved and be exchanged by the working collective. ${ }^{28}$ However, in July 1944 much of what Kollontai had achieved in the Soviet Union was undone following orders of Stalin. ${ }^{29}$ This must obviously have been a setback for Kollontai.

She left her post as people's commissar already in 1918. One reason was that she was unhappy with the terms of the treaty of Brest-Litovsk. ${ }^{30}$ Another reason could be that her lover Dybenko was threatened with execution as he had given up Narva to German troops without cause. ${ }^{31}$ Kollontai and Dybenko married while Dybenko was in prison and this very likely saved him. He was later acquitted from his crime. Dybenko was executed in 1938 during Stalin's purges. ${ }^{32}$

In 1921 Kollontai supported the opposition within the Bolshevik party. This opposition criticised the growing decline of freedom of speech and the direction the party had taken after the revolution. ${ }^{33}$ It was crushed by Lenin and Kollontai had to largely leave Moscow's political scene. Kollontai turned to Stalin, distanced herself from the opposition and asked for a position abroad. ${ }^{34}$ This resulted in her being sent to Norway where her first mission was to get the Norwegian state to recognize the Soviet Union, which succeeded in 1924. ${ }^{35}$

27 Agneta Pleijel, "Afterword” in Alexandra Kollontai. Arbetsbiens kärlek, 225.

28 Ibid., 227.

29 Ibid., 228.

30 Krister Wahlbäck, "Preface" in Aleksandra Kollontajs dagböcker 1930-1940, 12.

31 Ulrika Knutson, Kvinnor på gränsen till genombrott: Grupporträtt av Tidevarvets kvinnor (Stockholm: Bonniers, 2004).

32 Krister Wahlbäck, "Preface" in Aleksandra Kollontajs dagböcker 1930-1940, 27.

33 Agneta Pleijel, "Afterword" in Arbetsbiens kärlek, 231.

34 Krister Wahlbäck, "Preface" in Aleksandra Kollontajs dagböcker 1930-1940, 12.

35 Vladimir Kollontai et al., Revolusjon, Kjaerlighet, Diplomati: Aleksandra Kollontaj og Norden, ed. Yngvild Sörbye (Oslo: Unipub, 2008). 


\section{Kollontai in Sweden and her engagement in the Finnish Winter War}

In the autumn of 1930 Kollontai was elected as the new minister of the Soviet Union in Sweden, after previous positions in Mexico and Norway. She soon got active in creating a Swedish network and became friends with several people involved in the Swedish women's movement. Among these were the doctors Ada Nilsson and Nanna Svartz and the lawyer Eva Andén.

Stalin's purges started in 1934 and several Soviet diplomats disappeared - among these the ambassadors to Germany, Austria, Japan, Spain and Czechoslovakia. ${ }^{36}$ At the end of the 1930s only Kollontai, Stalin and Trotsky (who was murdered in 1940) were alive among the 13 members of the 1917 Petrograd soviet's presidium. ${ }^{37}$

The Finnish Winter War started in November 1939, which resulted in strong resentment towards the Soviet Union in Sweden and large parts of Europe. Stockholm became a city were important diplomatic contacts and discussions took place to attain peace. The main participant in the discussion from Sweden was foreign minister Christian Günther, aided by the cabinet secretary Erik Boheman. ${ }^{38}$ Boheman writes in his autobiography På vakt (1964) that Kollontai was one of the most fascinating diplomats he had ever met and that she must have had a strong position with Stalin as he never met another Soviet diplomat that could express herself as freely as Kollontai. ${ }^{39}$ Boheman also writes that Kollontai certainly was a communist believer and devoted to her early revolutionary ideal but that she had developed a deep sense of humanity and a kind of mildly philosophical approach to events and humans. Boheman thought that above all she was a great Russian patriot, albeit with warm feelings towards Finland and sympathies towards Sweden. According to Boheman, Kollontai did everything in her power to make relations between Sweden and the Soviet Union as good as possible and she played a substantial role in attaining the armistice between Finland and the Soviet Union in September 1944.

36 Teddy J Uldricks “The Impact of the Great Purges on the People's Commissariat of Foreign Affairs" in Slavic Review 35:2 (June 1977), 187-204.

37 Agneta Pleijel, "Afterword” in Arbetsbiens kärlek, 242.

38 Ulf Brandell "Christian E Günther: Diplomat, Utrikesminister”, Svenskt biografiskt lexikon, https://sok.riksarkivet.se/sbl/mobil/Artikel/13428 (accessed 1 July 2021).

39 Erik Boheman, På vakt (Stockholm: Norstedt, 1964). 
Kollontai writes in her diary that Finland was the barometer for Soviet relations with Sweden as each conflict with Finland sparked anti-Soviet feelings in Sweden. ${ }^{40}$ Her dedication to the Finnish cause may partly be explained by this political conviction of hers that good relations between Finland and the Soviet Union were required to cultivate good relations between Sweden and the Soviet Union. However, Kollontai herself had Finnish roots and was always sympathetic towards Finland, which may also have influenced her hard work during the war. Kollontai was suddenly summoned back to the Soviet Union in 1945, for reasons not completely known.

\section{Kollontai's Swedish contacts}

When Kollontai summarises her life in her biography she writes that her main accomplishments lay in three different fields: (1) Her efforts in the struggle for liberation and equality of working women. ${ }^{41}$ She writes that: "Women and their fate has kept me occupied all my life. It was their cause that brought me to socialism." 42 (2) Her international work with agitation and propaganda before the revolution. ${ }^{43}$ (3) Her efforts in politics to strengthen the Soviet Union, i.e. her diplomatic work. ${ }^{44}$

Kollontai was a famous person in Sweden during her time as ambassador. The journalist and social reformer Else Kleen writes in the daily newspaper Stockholms-Tidningen in 1944: "Alexandra Kollontai is without doubt the most famous of all women living in our country, and she is probably the only one whose work is going to stay alive in distant future memories." 45

40 Alexandra Kollontai, Aleksandra Kollontajs dagböcker 1930-1940, trans. Lars Olsson (Falun: Bonniers, 2008), 95.

41 Alexandra Kollontai, Jag har levt många liv, 293.

42 Ibid., 299. Translated from Swedish by the authors. Original text: "Kvinnorna och deras öde har sysselsatt mig i hela mitt liv. Det var deras lott som förde mig till socialismen."

43 Ibid., 295.

44 Ibid., 296.

45 Else Kleen, article about Kollontai, Stockholms-Tidningen, September 17, 1944. Translated from Swedish by the authors. Original text: "Alexandra Kollontay är utan tvekan den berömdaste av alla kvinnor som bor i vårt land, och hon är troligen den enda av världshistorisk betydelse, den enda vilkens verk kommer att leva i minnet i en avlägsen framtid." 
In 1935 an association was created to further cultural and scientific contacts between Sweden and the Soviet Union. ${ }^{46,47}$ Its two initiators were Kollontai and the professor of chemistry Wilhelm Palmaer ${ }^{48}$. Other original members were Ada Nilsson (physician), Nils Silfverskiöld (physician), Elin Wägner (author), Israel Holmgren (physician) and The Svedberg (chemist). ${ }^{49}$ Kollontai maintained a constant presence in this association throughout the years. ${ }^{50}$ Through her activity in this association Kollontai learned to know several academics sympathetic to the Soviet cause and also became close friends with several of them. Several of the members in the association were also active or engaged in the Fogelstad Group and its surrounding associates who were prominent pacifists and feminists.

\section{Ada Nilsson (1872-1964)}

\section{The Fogelstad Group and initial contact with Alexandra Kollontai}

Ada Nilsson studied medicine in Uppsala and Stockholm and soon developed left-wing sympathies as a newly graduated physician. ${ }^{51,52}$ She later specialised in gynaecology.

In 1921 five women - Ada Nilsson, Elisabeth Tamm, Elin Wägner, Honorine Hermelin and Kerstin Hesselgren started the female municipality college at Fogelstad. ${ }^{53}$ The idea behind the college was to educate women so they would be able to utilise their civil rights. The college also became a sort of sanctuary where women could meet and exchange ideas and experiences. The same group of women started the weekly journal Tidevarvet in 1923. The Fogelstad Group was tightly associated with feminist and

46 Carin Hermelin, Tre års verksamhet 1935-1938: Sällskapet för främjande av kulturella och vetenskapliga förbindelser mellan Sverige och Sovjetunionen (Stockholm: Zetterlund \& Thelander, 1938), 3 - available in Ada Nilsson's archive in Gothenburg.

47 Eva Palmaer, Tio års verksamhet 1935-1945: Sällskapet för främjande av kulturella och ekonomiska förbindelser mellan Sverige och Sovjetunionen (Stockholm: Västermalm 1945), 4 - available in Ada Nilsson's archive in Gothenburg.

48 Carin Hermelin, Tre års verksamhet 1935-1938, 3.

49 Ibid., 4.

50 Eva Palmaer, Tio års verksamhet 1935-1945, 5.

51 Ada Nilsson, Glimtar ur mitt liv som läkare (Stockholm: Natur och Kultur, 1963), 25.

52 Ulrika Nilsson, Det heta könet: Gynekologin $i$ Sverige kring förra sekelskiftet (Stockholm: Wahlström \& Widstrand, 2005), 290, 294.

53 Jan Halldin, "Stalins diplomat i Sverige överlevde trots sin ohälsa”, Läkartidningen 2008:41. 
pacifist values and believed in equal pay for equal work, as well as the need for sexual education and contraception. Kollontai shared many of these ideas with the group and was later on engaged in its work. The members of the Fogelstad Group were very active both socially and politically.

When Kollontai arrived in Sweden in 1930 she quickly came to the conclusion that the communist party there had very little influence after it had been split into rival factions. ${ }^{54}$ Moreover, there were strong antipathies towards the Soviet Union in Sweden. She writes in a letter to a friend that the Swedes still remembered the battle of Poltava in 1709 and that they feared the "'Russian bear' no matter if he is led by the crown of the tsar or the five-pointed star." 55 Kollontai saw the need of creating allies in Sweden to be able to achieve her diplomatic work. She quickly identified a group of pacifist women, i.e. mainly the members and associates of the Fogelstad Group and Tidevarvet that sympathised with the Soviet Union's stance on peace and singled out Ada Nilsson as their leader. ${ }^{56}$ Nilsson was nice, popular, politically active and already sympathised with the Soviet Union and defended it in the newspapers. Nilsson helped to bring about an interview with Kollontai in Tidevarvet and shortly after invited her to take part in a seminar series about the Soviet Union. ${ }^{57}$ Kollontai was happy to accept these invitations and thereby came into contact with a group of intellectuals that sympathised with the Soviet Union. The first time Kollontai and Nilsson met was in Nilsson's home at a reception for Kollontai after her interview by Tidevarvet. ${ }^{58}$ Shortly after, Kollontai invited Nilsson to her home and asked for her help in recommending physicians of different specialities in case anyone in the Soviet legation fell ill. ${ }^{59}$ Nilsson became Kollontai's own personal physician and therefore got very close to her.

It seems like Kollontai early on singled out Ada Nilsson as a useful contact and through her she also became acquainted with several leading figures within the pacifist and women's movement in Sweden. Kollontai wanted to get close to the pacifist circles in Sweden - the Soviet Union had early on taken on the role as one of the main advocates for peace in

\footnotetext{
54 Alexandra Kollontai, Aleksandra Kollontajs dagböcker 1930-1940, 71.

55 Ibid., 82. Translated from Swedish by the authors. Original text: “"den ryska björnen' vare sig han är iförd tsarkrona eller femuddig stjärna."

56 Ibid., 71.

57 Ibid., 82.

58 Ada Nilsson, Glimtar ur mitt liv som läkare, 131.

59 Ibid., 131.
} 
the world and this echoes throughout Kollontai's actions. She noticed that Fascism and Nazism were gaining increased influence and writes in her diary in 1931 that she has to work hard for the Union's position when it came to disarmament and that she had to activate the pacifists in Sweden. ${ }^{60}$ She concludes that the main person she therefore had to talk to was Ada Nilsson. Ada Nilsson also became a leading member of the Association for Furthering Cultural and Scientific Connections between Sweden and the Soviet Union, an organisation partly founded by Kollontai.

\section{Friendship}

Kollontai and Nilsson first got into contact with each other due to shared political views and values. Kollontai, as well as Nilsson, supported pacifism and also the liberation of women. Nilsson was a prolific author of writings championing the need for sexual education, reproductive health and that abortions should be legal. She also travelled a lot to lecture about these topics. ${ }^{61}$ As has been mentioned, Kollontai was involved in bringing about new laws concerning these topics in the Soviet Union, although most was undone in the 1940's because of the war efforts and political priorities. In Nilsson she found someone who shared her ideas in this respect. As a matter of fact, these shared ideas were repressed not only in the Soviet Union, but also in Nazi Germany at the time, as both countries wanted to increase their population to create more soldiers for the future. Kollontai must have felt conflicted about this as her own convictions no longer were representative of those of her country.

Over the years Kollontai and Nilsson cultivated a strong friendship based on true companionship, and not only on political motives. Kollontai describes her friendship to Nilsson in a letter in 1936: "You are a brave human and I do not only love you, I admire you. So it is!" 62 In a letter from 1945, after she had returned to the Soviet Union, Kollontai tells Nilsson that she is and will remain her best friend. ${ }^{63}$

60 Alexandra Kollontai, Aleksandra Kollontajs dagböcker 1930-1940, 162.

61 Kristina Lundgren, "Ada Konstantia Nilsson", Svenskt kvinnobiografiskt lexikon, 8 March 2018, www.skbl.se/sv/artikel/AdaNilsson (accessed 8 June 2021).

62 Letter from Alexandra Kollontai to Ada Nilsson, dated 13 August 1936 at Mariestad stadshotell - available in Ada Nilsson's archive at the Gothenburg University Library. Translated by the authors from Norwegian and Swedish. Original text: "Du er en mudig menniske og jag icke bare elsker dig men beundra Dig. So er saken!"

63 Letter from Alexandra Kollontai to Ada Nilsson, dated 21 May 1946 at Bolshaya Kaluzhskaya 11, kvartira 149 - available in Ada Nilsson's archive at the Gothenburg University Library. 


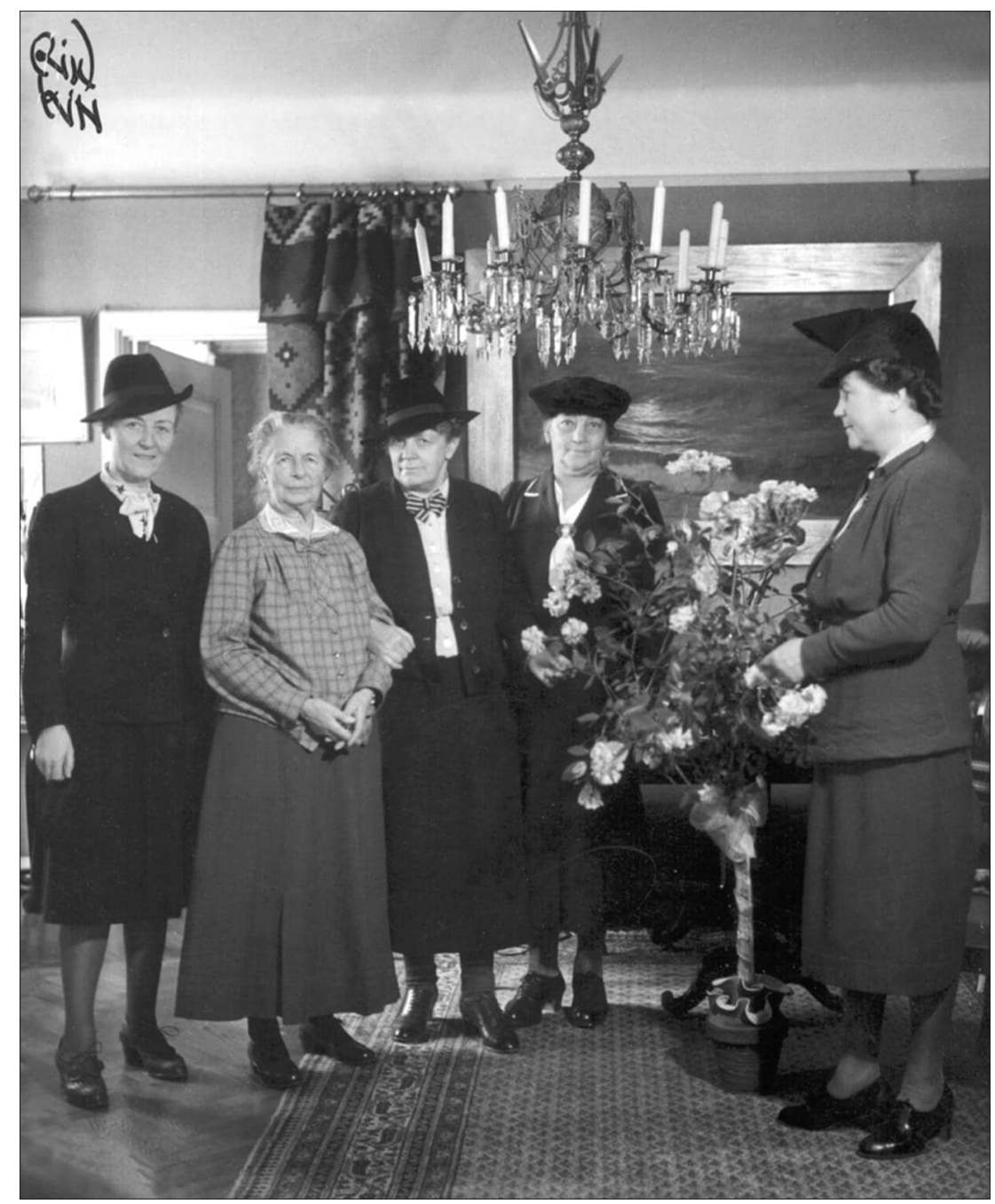

From the left: Andrea Andreen, Karolina Widerström,

Ada Nilsson, Anna Johansson-Visborg and one unidentified woman.

Unknown photographer. Available at KvinnSam,

Gothenburg University Library 
Kollontai also tells Nilsson several things that seem very unlikely to tell anyone but a close friend. Nilsson seems to be a confidante of Kollontai's. For example, Nilsson writes that Kollontai was very aware that she was constantly monitored by a GPU-representative and she always told Nilsson who currently had the position. ${ }^{64}$ According to bugged information from Kollontai's phone (the Swedish secret service started to bug Kollontai's phone in 1939) Nilsson sometimes helped Kollontai to decide whether she could trust that some specified Swedes really sympathised with her cause. ${ }^{65}$

How much Kollontai trusted Nilsson also becomes apparent as Nilsson is the only one she entrusts her personal documents to. In 1937 Kollontai asks Nilsson to take care of her personal letters, notes, diaries and other personal material until 1947 (in case an accident happens to her) and then deliver the material to the Marx Engels Institute in Moscow. ${ }^{66}$ On the 31 July 1938, Kollontai phoned Nilsson to meet up with her at the Grand Hotel Saltsjöbaden outside Stockholm. ${ }^{67}$ There, Nilsson received stacks of letters which Kollontai asked her to burn (as she could not do it herself at the hotel). ${ }^{68}$ In addition there was a personal letter to Nilsson with some instructions of what was to be done if something happened to Kollontai. ${ }^{69,70}$ It is unknown what Kollontai feared would happen in the late 1930s to prompt these actions, but in any case she deemed it necessary to take precautions when it came to her personal material and the one person she trusted with it was Ada Nilsson. In addition to this it was to Nilsson her personal secretary was going in 1942, after Kollontai's stroke, to deliver her diaries when she was caught up by the KGB-agent. It seems like Kollontai and Ada Nilsson first met due to shared political ideas but then developed a strong companionship that lasted until Kollontai's death in 1952.

\footnotetext{
64 Ada Nilsson, Glimtar ur mitt liv som läkare, 144.

65 Krister Wahlbäck, "Preface" in Aleksandra Kollontajs dagböcker 1930-1940, 25-26.

66 Ada Nilsson, Glimtar ur mitt liv som läkare, 169.

67 Ibid., 142.

68 Notes for the manuscript of Ada Nilsson's biography by Ada Nilsson, available in Ada Nilsson's archive at the Gothenburg university Library.

69 Ibid.

70 Ada Nilsson, Glimtar ur mitt liv som läkare, 142.
} 


\section{Andrea Andreen (1888-1972)}

Andrea Andreen came from a religious home and studied medicine in Uppsala. Later on she specialised in internal medicine. She became a pioneer in diabetes treatment but also had strong pacifist views and believed in equal rights between men and women. ${ }^{71}$ She is most known for her work in the scientific commission in Korea and China in 1952. This commission was to investigate the level of truth in the allegations that the US used bacterial warfare in the Korean War. The commission concluded that China and the People's Republic of Korea had been subjected to bacterial warfare from US forces. The conclusion was heavily criticized in the media. Andreen herself was subjected to a witchhunt spearheaded by some of the most prominent newspapers in Sweden and was often referred to as being used as a tool to further Soviet interests. ${ }^{72}$ Andreen was awarded the Stalin Peace Prize in 1953 for her work towards world peace, including her efforts in Korea. The Stalin Peace Prize was created in 1949 and was awarded on Stalin's birthday, the $21^{\text {st }}$ of December. It could be awarded to citizens of any country and was to be awarded without regard to political views, religion or race.

During this time there existed a disappointment surrounding the Nobel Peace Prize in some circles. These groups of people thought that although the Nobel Peace Prize originally was awarded to true peace workers it had lost its purpose during later years. As an example the Nobel Peace Prize was awarded to General George C. Marshall in 1953; he was responsible for the Marshall plan to rebuild Europe but had also taken part in the decision to use atomic bombs in Hiroshima and Nagasaki. Therefore the decision to award him the Nobel Peace Prize was seen as a betrayal by several peace workers. To these, the Stalin Peace Prize came to fulfil the original aim of the Nobel Peace Prize. However, the Stalin Peace Prize had dual functions - it partly awarded peace work, even among non-communists, but also had political ramifications. It can be compared to the "United Front Strategy" that the Communist International (Comintern) used during the 1930s. Based on this strategy they favoured political cooperation on a wider front, compared to their earlier isolationist strategy where no

\footnotetext{
71 Alexandra Nicolaidis \& Peter Nilsson, "Läkaren Andrea Andreen”.

72 Ibid.
} 
cooperation with social democrats was allowed, to battle the threats posed by Nazism and Fascism.

In 1917 Andreen started work as a young doctor at Julita, a small community in mid-Sweden. She was drawn there by Elisabeth Tamm, one of the members of the Fogelstad Group, who allowed Andreen to live with her at Fogelstad..$^{73}$ Due to this, Andreen got into contact with the other women in the Fogelstad Group, including Ada Nilsson and Kollontai. Kollontai lectured at the Fogelstad municipality school and was therefore a frequent guest there. ${ }^{74}$

When Kollontai was creating the Association for Furthering Cultural and Scientific Connections between Sweden and the Soviet Union, she wrote directly to Andreen to invite her to the first meeting. ${ }^{75}$ Andreen visited the Soviet Union several times, not least to collect the Stalin Peace Prize. She frequently lauded the Soviet peace struggle in interviews and writings and was named one of the world's four most prominent "red women" by the Russian weekly newspaper Ogoniok in $1954 .{ }^{76}$ Despite being known for being sympathetic towards the Soviet Union, Andreen was never a member of the association.

Kollontai and Andreen knew each other and shared some political views. They were friends but far from as close to each other as Kollontai and Ada Nilsson. Furthermore, much of Andreen's strongest activities in the peace- and women's movement took place shortly before or after Kollontai's return to the Soviet Union. However, Kollontai followed Andreen's writings and admired her fight for peace. ${ }^{77}$ After Kollontai's return to the Soviet Union she continued to follow Andreen's doings in the peace- and women's movement and tried to read most of what was written by and about Andreen.

73 Ulrika Nilsson, Det heta könet, 306.

74 “Kvinnliga medborgarskolan vid Fogelstad”, Gothenburg University Library, http:// www2.ub.gu.se/kvinn/portaler/kunskap/databas/public.xml?id=222\&detail=1 (accessed 2 July 2021).

75 Letter from Alexandra Kollontai to Andrea Andreen (Stockholm, 2 March 1935) available in Andrea Andreen's archive at the Gothenburg University Library.

76 Alexandra Nicolaidis \& Peter Nilsson, "Läkaren Andrea Andreen”.

77 Letter from Alexandra Kollontai to Andrea Andreen (Bolshaya Kaluzhskaya, 18 February 1951) - available in Andrea Andreen's archive at the Gothenburg University Library. 


\section{Nanna Svartz (1890-1986)}

\section{Background}

Nanna Svartz studied medicine in Stockholm and Uppsala. ${ }^{78}$ Svartz specialised in internal medicine and became an expert physician and researcher in the areas of rheumatic illnesses and illnesses of the gastrointestinal system. In 1937 Svartz became the first ever Swedish female professor at a state-owned institution (Karolinska Institute). She had several famous patients - e.g., the Swedish king Gustav V and field-marshal Gustaf Mannerheim.

Gunilla Lindberg names her an icon in her book Starka kvinnor som fört Sverige framåt (2005) and describes her in the following way:

"Admired, worshipped by some but also portrayed as a monster by others. Some thought she was power-hungry because of her many leading positions. A true worker that toiled sixteen hours per day and was subjected to several intrigues and academic slurs during her career. An outstanding scientist in the rheumatic diseases and the bacteria of the intestine. A physician hired by a long row of contemporary celebrities to whom the name Nanna Svartz was the best guarantee to overcome a critical illness." 79

\section{Kollontai's stroke}

The first time Svartz met Kollontai was in 1936 at a reception held at the Soviet embassy for the participants of the Fifth International Congress of Rheumatology that took place in Sweden. ${ }^{80}$ After this, several years passed when they did not have much contact.

78 Ulrika Nilsson, "Nanna Charlotta Svartz", Svenskt kvinnobiografiskt lexikon, 8 March 2018, https://skbl.se/sv/artikel/NannaSvartz (accessed 8 June 2021).

79 Gunilla Lindberg, Starka kvinnor som fört Sverige framåt (Hudiksvall: Winberg Citybook AB, 2005), 202. Translated from Swedish by the authors. Original text: "Beundrad, dyrkad av vissa men också framställd som ett monster av andra. Maktgalen tyckte några med tanke på hennes många chefsbefattningar. En sann arbetsmänniska som slet sexton timmar om dygnet och utsattes för åtskilliga intriger och akademiskt förtal under sin karriär. En framstående forskare kring de reumatiska sjukdomarna och tarmkanalens bakterier. En läkare anlitad av en lång rad av den tidens kändisar för vilka namnes Nanna Svartz var den bästa garanten för att man skulle klara av en svår sjukdom.”

${ }^{80}$ Magnus Ullman, Kvinnliga pionjärer verksamma i Sverige (Stockholm: Bokförlaget Magnus Ullman, 2004), 251. 
In mid-august 1942, Kollontai had been sitting at her desk for eight hours straight when she decided to retire for the night. She then suffered a major stroke and was brought to the Red Cross medical facility. ${ }^{81}$ When news reached Moscow, Stalin sent a message to the stand-in chargé d'affairs Vladimir Semyonov, asking everyone to do everything they could for Kollontai.

The day after the stroke, Kollontai's secretary called Ada Nilsson and told her what had happened. Nilsson, being a gynaecologist herself and thus lacking the expertise required, suggested that they should send an airplane to pick up Svartz from a conference in Falkenberg. When Svartz was contacted she readily accepted to hurry back to Stockholm. Svartz took over the medical care of Kollontai and treated her with heparin injections, which at this time was a controversial treatment. ${ }^{82}$ Kollontai survived, probably due to the heparin injections, although she was confined to a wheel-chair for the last ten years of her life. After this event Kollontai was very grateful towards Svartz. Kollontai continually expressed gratitude to Svartz for saving her life and was convinced that it was Svartz' competence that gave her the chance to live and work for several years after that event. ${ }^{83}$

When Kollontai was summoned back to the Soviet Union in 1945 she had recently recovered from a flu that had developed to pneumonia. Svartz therefore accompanied her to the Soviet Union to relay to her Soviet colleagues what treatment had been given. ${ }^{84}$ However, Kollontai soon fell ill again with the flu and developed hepatitis. Svartz therefore remained at her quarters for several weeks before returning to Sweden.

The friendship between Kollontai and Svartz seems to have started in 1942 when Svartz cared for Kollontai. However, it seems to have properly bloomed during Svartz' stay with Kollontai in Moscow in 1945. Kollontai wrote about a hundred letters between 1942 and 1952 to Svartz and repeatedly referred to the time when Svartz stayed with her in Moscow in 1945. ${ }^{85}$

81 Ada Nilsson, Glimtar ur mitt liv som läkare, 156.

82 Ibid., 157.

${ }^{83}$ Letter from Alexandra Kollontai to Nanna Svartz (Bolshaya Kaluzhskaya 11 kvartira 149, 6 April 1947) - available in Nanna Svartz' archive at the national archives in Stockholm.

84 Ada Nilsson, Glimtar ur mitt liv som läkare, 163.

85 Letters available in Nanna Svartz' archive at the national archives in Stockholm. 
She writes that she thinks often of Svartz and that she felt like Svartz was part of her home and life in Moscow during the time she stayed there. ${ }^{86}$ She writes the following in a letter to Svartz from 1945: "A piece of my heart and open sympathy still lies in Sweden. I miss my friends, and I count the professor as one of the closest among them." 87

The letters between Kollontai and Svartz mainly concern everyday matters and they talk very little about medical problems. Mentions of political character are also quite rare in their communication. In general the communication focuses on everyday common matters and Kollontai's gratitude towards Svartz' contributions to her health and friendship.

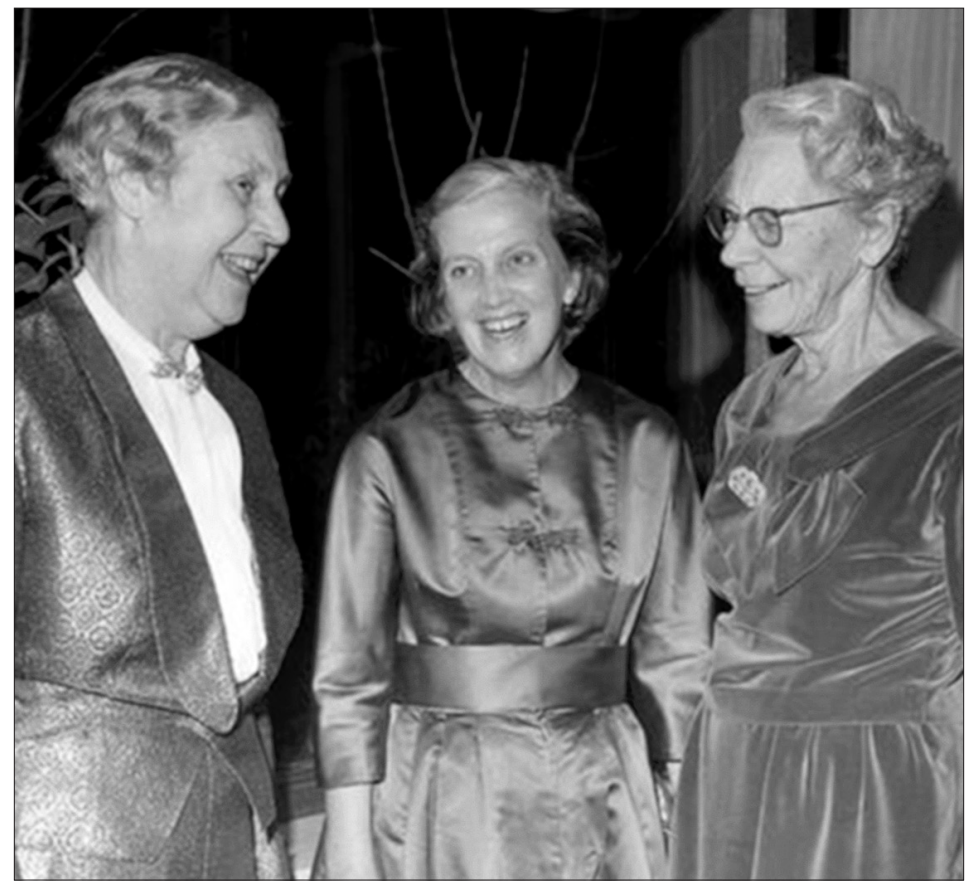

From the left: Nanna Svartz, Dorothy Hodgkin and Karin Kock, 1964. Available at TT News Agency, Stockholm

${ }^{86}$ Letter from Alexandra Kollontai to Nanna Svartz (Moscow, 21 August 1945), available in Nanna Svartz' archive at the national archives in Stockholm.

87 Ibid. Translated from Swedish by the authors. Original text: "En del av mitt hjärta och uppriktig sympati är fortfarande kvar i Sverige. Jag saknar mina vänner, och jag räkna Professorn som en av de närmaste bland dem." 
Svartz had ideas that mirrored those of Kollontai: She thought it best if working women with careers would have a maid or a nurse, but she understood that not everyone could. ${ }^{88}$ She herself had a nurse, assisted by her grandmother, to take care of her child and she thought there should be kindergartens available for everyone. Moreover she thought there should be municipal cleaning centres spread around the cities that could assist working women, or the elderly, with cleaning services a couple of times a week for an acceptable sum. These ideas corresponded well with Kollontai's thoughts on the matter and although politics seems to have played a minor role in their relationship it seems likely that these shared thoughts helped to build their friendship.

\section{Discussion}

This article has investigated the friendly relationships between three Swedish female physicians and Alexandra Kollontai. However, apart from the connections between Kollontai and the physicians there were also connections between these physicians. They all three knew each other and interacted with each other.

Ada Nilsson and Andrea Andreen shared many interests, apart from both being physicians. Both were involved in the pacifist movement in Sweden and were dedicated to women's liberation and sexual education. Both Nilsson and Andreen were members of SKV. ${ }^{89,90}$

Nilsson was never a member of any political party and Andreen left the Social Democrats after they deemed it inappropriate to be a member of SKV. ${ }^{91,92}$ Nilsson was a member of the Fogelstad Group and Andreen was close to this group and had many interactions with it. In their letter communication much is focused around the peace movement and their work in common organisations. ${ }^{93}$ Both Andreen and Nilsson were also involved in the socialist and antifascist journal and organisation

\footnotetext{
88 Gunilla Lindberg, Starka kvinnor som fört Sverige framåt, 212.

89 Kristina Lundgren, "Ada Konstantia Nilsson".

90 Alexandra Nicolaidis \& Peter Nilsson, "Läkaren Andrea Andreen”.

91 Ibid.

92 Kristina Lundgren, "Ada Konstantia Nilsson".

93 Letters available in Andrea Andreen's archive at the Gothenburg University library.
} 
Kulturfront. In 1938 Kulturfront was split into two factions due to disagreement on whether the organisation should protest against Stalin's purges or not. Nilsson was one of the members that voted against making a protest. ${ }^{94}$

Svartz was not a member of the pacifist and women's right organisations that Andreen and Nilsson were. She seems to have spent most of her time with work purely in the medical sector, but did have a belief in the equal rights of women and must have found common ground for these thoughts together with Andreen and Nilsson. She was friendly to both of them and was ready to return immediately to Stockholm when Nilsson asked her to for the sake of Kollontai. In the communication between Svartz and the other two much is centred around their medical work, the working conditions in their different clinics and accounts about recent medical cases. ${ }^{95}$

Andreen and Svartz seem to have had a mutual admiration for each other. Andreen writes in a letter to Svartz: "You mean so much - for science, for the healthcare, for the young doctors, for women in healthcare (and I do think that the influence women have in the community is needed for a better healthcare), for female physicians in Sweden, for your friends, for me." 96 Likewise Svartz writes about the admiration that Andreen's scientific work has sparked. ${ }^{97}$

It has to be noted that the archives studied for this article may have been deliberately incomplete as either the women themselves, or others, may have gone through and removed material. Moreover, there may also exist legal obstacles that prevent full access to parts of archives, e.g. the transcripts from the bugging of Kollontai's phone by the Swedish secret service and parts of Nanna Svartz' archive that are deemed confidential.

94 Kulturfront (1935-1938), Demokratikämparna, accessed 15 August 2021 at https:// demokratikamparna.wordpress.com.

95 Letter from Nanna Svartz to Andrea Andreen (Stockholm, 21 February 1921), available in Andrea Andreen's archive at the Gothenburg university library.

96 Letter from Andrea Andreen to Nanna Svartz (Stockholm, 9 November 1950), available in Nanna Svartz' archive at the national archives in Stockholm. Translated from Swedish by the authors. Original text: "Du betyder så mycket - för vetenskapen, för sjukvården, för de unga medicinarna, för kvinnornas sak i vården (och jag tror ju att kvinnornas samhällsinflytande behövs för en bättre vård), för Sveriges kvinnliga läkare, för dina vänner, för mig."

97 Letter from Nanna Svartz to Andrea Andreen (9 May 1933), available in Andrea Andreen's archive at the Gothenburg university library. 


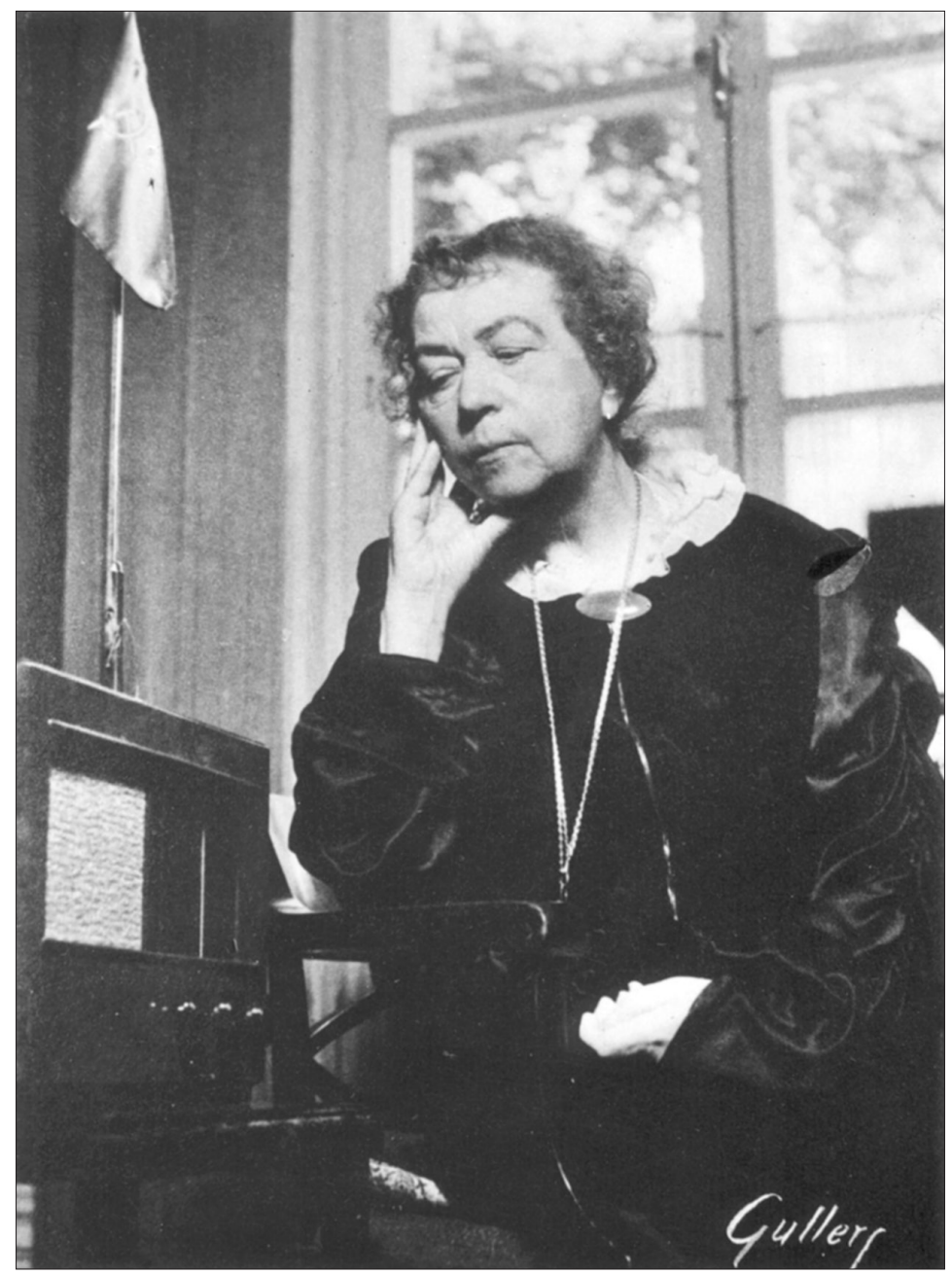

Alexandra Kollontai sitting by a radio

with a Soviet flag, 1944. Photography taken by K. W. Gullers. Available at KvinnSam, Gothenburg University Library

When it comes to the letter collections studied for this article it is acknowledged that the studied documents only depicts the communication from one side, i.e. the authors have had access to the letters sent by Alexandra Kollontai to the physicians but not to the letters sent back to Kollontai. These are kept in the personal archives of Kollontai that are deposited in 
the Russian State Archives for Social and Political History (Rossiiskii gosudarstvennyi arkhiv sotsial'no-polticheskoi istorii) in Moscow.

Previous research on Kollontai and her life has been discussed. It focuses mainly on her political work and agenda, and not least her role during the October revolution and work as a Soviet diplomat. Her friendship and contacts with Swedish female physicians has not been investigated much at all.

In the future it would be of value studying to what extent Alexandra Kollontai influenced the political views of these three female physicians and if she led them towards pro-Soviet ideas. That she influenced them to some extent seems apparent. Kollontai's ideas found resonance with these three physicians. Ada Nilsson and Andrea Andreen shared opinions with Kollontai when it came to peace and women's rights. Kollontai and Nanna Svartz shared similar ideas about the dissolution of the core family concept. However, it seems feasible that all parts have influenced each other to some extent in their ideological sympathies.

\section{Conclusions}

There existed friendly relationships between Alexandra Kollontai and several female Swedish physicians. Even though some of the contacts started as politically convenient connections there seems to have grown true friendship between Kollontai and the physicians over the years.

They all shared similar ideas around the women's movement and several of them were members of the same organisations. To exemplify, Nilsson was a member of the Association for Furthering of Cultural and Scientific contacts between Sweden and the Soviet Union, an association partly founded by Kollontai. In the end, the connections between Kollontai and the physicians led to lasting friendships between them that lasted until Kollontai's death in 1952.

\section{Acknowledgements}

Heartfelt thanks are directed to the KvinnSam Department at the Gothenburg University Library and the National archives in Stockholm for great assistance and help with archival studies during the ongoing pandemic. 


\title{
Aleksandra Kolontaja un trīs zviedru ārstes: Padomju Savienības vēstnieces draudzīgās attiecības Stokholmā laika posmā no 1930. līdz 1945. gadam
}

\section{Kopsavilkums}

Aleksandra Kolontaja bija Padomju Savienības vēstniece Zviedrijā laika posmā no 1930. līdz 1945. gadam. Viṇa tur ieguva daudz draugu miera un sieviešu kustībā, un šo draugu vidū bija vairākas ārstes. Šajā publikācijā ir pētîta un raksturota draudzība starp Aleksandru Kolontaju un trim ārstēm: Adu Nilsoni (Ada Nilsson, 1872-1964), Andreu Andrēnu (Andrea Andreen, 1888-1972) un Nannu Svartsu (Nanna Svartz, 1890-1986).

Ir atklāts, ka starp Kolontaju un šīm ārstēm izveidojās patiesi dziḷa draudzība, lai gan sākotnēji viṇu komunikācijai bija tikai politiski un medicīniski iemesli.

Atslēgvārdi: medicīnas vēsture, Aleksandra Kolontaja, Padomju Savienība, Zviedrija.

\author{
Alexandra Nicolaidis \\ $M D, P h D$ studente, Medicīnas vēstures katedra, Lundas \\ Universitāte, Zviedrija / MD, PhD student, Department \\ of History of Medicine, Lund University, Sweden \\ Peter M. Nilsson \\ Profesors, $M D, P h D$, Medicīnas vēstures katedra, Lundas \\ Universitāte, Zviedrija / Professor, $M D, P h D$, Department \\ of History of Medicine, Lund University, Sweden

\footnotetext{
David Dunér

Profesors, $P h D$, Mākslas un kultūras zinātṇu katedra, Lundas Universitāte, Zviedrija / Professor, PhD, Department of Arts and Cultural Sciences, Lund University, Sweden
} 